Jackeline Lima Farbiarz , Alexandre Farbiarz [PUC/Rio]

\title{
Design da leitura: uma questão de conduta
}

Design for reading: an issue of conduct

design da leitura, educação, material didático-paradidático

O Design, enquanto campo de vocação interdisciplinar, pressupõe a existência de unidades formadoras voltadas para o conhecimento e a reflexão acerca de diferentes áreas de atuação. O designer, por este viés, assume a responsabilidade de mais do que conhecer as diretrizes específicas de sua formação, conhecer, observar e participar de áreas de conhecimento diferentes da sua para, só então, intervir. Em alguns momentos, contudo, a estrutura do mercado inviabiliza uma intervenção consistente por parte do designer, ou seja, uma intervenção calcada tanto nas diretrizes específicas de sua formação quanto na realidade do campo em que sua ação está sendo solicitada. Em outros momentos, o próprio designer tem um conhecimento limitado do campo em que irá intervir, o que pode acarretar em uma intervenção aquém das possibilidades e/ou contribuir para a manutenção de preconceitos sociais. O propósito deste artigo é discutir a atuação do designer no campo da Educação, analisando a sua contribuição na elaboração de material didático e paradidático voltado para a temática da leitura. Enfatiza-se neste artigo o duplo papel de formaçãoinformação do designer que ora por impossibilidade ora por desconhecimento pode vir a gerar preconceitodesinformação.

design for reading, education, didactic and para-didactic material

Design, as a field with inter-disciplinary vocation, appraises both the existence of knowledge formative units and the assessment of different performance areas. From this perspective, before executing job interventions, a designer should undertake a responsibility higher than merely knowing his specific instruction guidelines, i.e., observe, get acquainted to, and participate of knowledge fields which may be different from his own. However, sometimes market's structure turns a consistent intervention unattainable, i.e., an intervention grounded both on his instruction specific guidelines and on the field's reality, for which his performance is being needed. At other moments, the designer has a limited knowledge of the field in which he will perform the intervention, and this may cause the intervention to be impossible and/or contribute to generate social prejudice. This paper aims to discuss the designer performance in the educational field, analysing its contribution to the development of didactic and para-didactic material related to reading. We emphasize the double role of the designer's skills and information which, sometimes due to an impossibility otherwise to unawareness, may lead him to the generation of social prejudice and to the lack of informative content.

Fertilizando e deixando fertilizar-se por outras áreas de conhecimento, o Design vem se construindo e reconstruindo em um processo permanente de ampliação de seus limites, em função das exigências da época atual. Em linha com esta tendência, sua vocação interdisciplinar impede um fechamento em torno de conceitos, teorias e autores exclusivos. Sua natureza multifacetada exige interação, interlocução e parceria.

RitaCouto e Alfredo Oliveira

No diálogo com o outro, eu não harmonizo as diferenças (que são essenciais à prática dialógica), não supero as frustrações que me são impostas pelos limites (efetivos) da comunicação, não elimino os riscos, porém aprendo a apreciar a polifonia, aprendo a ouvir a diversidade das vozes.

Leandro Konder 


\section{Infodesıg}

\section{O contexto educacional}

Dietzsch e Silva (1994), utilizando-se de uma personagem ficcional - a profa ${ }^{a}$. D. Margarida Sobral -, que poderia estar inscrita em grande parte das escolas brasileiras, observam o "nervosismo, o desânimo, o fazer sem desejos" que empurram para longe os sonhos e empobrecem até o cansaço o "sabor de se construir o saber". Ainda Dietzsch (1996) discorre sobre os encontros e desencontros do aprendiz com a leitura e a escrita, através das memórias de Graciliano Ramos. Sua fala se centra na insatisfação do menino Graciliano quanto a uma constante frustração de expectativa, originária de uma pedagogia que não desafia o aluno e que 0 mantém distante de seus sonhos e desejos. De um lado, uma professora que se sente inadequada, solitária no desencontro, de outro lado, um aluno insatisfeito, frustrado em suas expectativas. No meio,um material didático inadequado. Em comum o desencontro com o sonho, o descompasso.

Figuras centrais do espaço escolar, D. Margarida e o menino Graciliano, embora habitantes de salas de aula diferentes, fazem parte de uma mesma rotina escolar, mas, ao que parece, não se conhecem, ou melhor, não se reconhecem. Na aparência, representam figuras assépticas e amorfas com funções pré-definidas: D. Margarida expõe o saber, enquanto o menino Graciliano o apreende, muitas das vezes através de produtos com os quais não consegue dialogar. Como resultado, D. Margarida risca respostas e mais respostas e se indaga "como esse aluno não consegue acertar esta questão?" Enquanto o menino Graciliano se questiona, "para que me serve isto?". Dois elementos do esquema comunicacional que não dialogam, não interagem. Duas massas, aparentemente, amorfas.

A constatação do "fracasso escolar" já há algum tempo vem fazendo parte dos discursos que perpassam o ambiente educacional brasileiro. A frustração de $D$. Margarida e do menino Graciliano, apenas exemplificam aquilo que já não causa estranhamento, mas sim que confirma a expectativa do fracasso.

Ensinar e aprender pressupõe possibilitar e permitir a comunicação, porém durante a formação pedagógica de D. Margarida - representante de grande parte dos professores em atuação nos dias de hoje - a prática de ensino pautava-se no modelo comunicacional tal qual proposto por Jackobson (1969) ${ }^{1}$, o que pressupunha a existência de uma mensagem que passava incondicionalmente do emissor para o receptor, sem considerar as expectativas, 0 repertório ${ }^{2}$ e as motivações que alimentam e despertam o interesse deste. Como resultado, uma prática pedagógica que chega ao aluno através de materiais que deverão ser decodificados e não recodificados e um receptor com características de ledor ${ }^{3}$ e não de leitor.

Se a afirmativa "a escola fracassou" ganha cada vez um número maior de adeptos, quando a questão centra-se exclusivamente na leitura novas vozes se alevantam. D. Margarida e o menino Graciliano vêem seu desconforto agravado quando encontram novas personagens inscritas na prática pedagógica. D. Margarida poderia ser a professora de Literatura do ensino médio, responsável pela tarefa de manter, e muitas vezes de despertar, o interesse do adolescente pela leitura. Afinal é neste momento que se formaliza ou que se direciona o ensino da leitura, fragmentando-o e transformando-o em uma disciplina específica. O menino Graciliano poderia ser o adolescente de nossos dias, envolto em tecnologia e com a mesma questão central "pra que me serve isto?". Mudam-se as séries, fragmentam-se os conhecimentos, e o descompasso parece manter o seu ritmo: emissores de um lado, receptores de outro, materiais didáticos e paradidáticos inadequados e ausência de interação.

\footnotetext{
${ }^{1}$ O modelo de Roman Jackobson prevê os seguintes elementos no ato de comunicação: emissor, receptor, referente, mensagem, código e canal. Tal modelo desconsidera a possibilidade de imprevisões na mensagem, pautando-se na visão de um emissor que transmite incondicionalmente a mensagem ao receptor (Jackobson, 1969).

${ }^{2}$ A utilização do termo literário repertório prevê o seu entendimento dentro da ótica proposta por Wolfgang Iser, teórico da Escola de Constância da Estética de Recepção. Neste sentido, o fato de que leitores completamente diferentes podem ser diferentemente afetados pela "realidade" de um determinado texto evidencia o grau em que textos literários transformam a leitura num processo criativo que está bem acima da mera percepção do que está escrito. O produto desta atividade criativa é a dimensão potencial do texto; não é o texto em si, nem a imaginação do leitor: ela é a fusão de texto e imaginação.

${ }^{3}$ O que é ler? Esta foi a questão proposta na II Jornada Interdepartamental pelos pesquisadores dos Departamentos de Educação, Artes, Letras e Filosofia da PUC-Rio. Neste encontro uma das professoras da escola pública Luis Delfino estabeleceu a diferença entre leitor e ledor, considerando o último aquele que decodifica e o primeiro o que recodifica o texto.
}

\footnotetext{
' Motivadas por um produto final quase material - a própria alfabetização - parece alimentar esta prática, já que outras séries/processos escolares não encontrariam uma visibilidade tão grande em termos de resultados. (Lelis, 1996, p.185) '
} 
Se, a princípio não haveria diferenciação entre o descompasso da D. Margarida da $2^{\mathrm{a}}$ série do ensino fundamental e das possíveis Margaridas do ensino médio, a prática vem demonstrando que o desencontro com a leitura é algo diferenciado e não constante.

Lelis (1996), entrevistando professoras da classe de alfabetização, aponta para a satisfação destas no desenvolvimento de seus trabalhos.

Ouvindo o relato da professora Luiza, não da classe de alfabetização, mas da $4^{\mathrm{a}}$ série do ensino fundamental, Lelis se depara então com alunos extremamente motivados e leitores assíduos:

\begin{abstract}
' a primeira leitura eu deixei que eles fizessem, mas comecei a estimular livros que dou na $5^{a}$ série do ensino fundamental... Eles reclamaram "tia é muito grosso!" Eu falei:Vocês têm que procurar livros mais maduros, de aventura, sair um pouco daqueles de histórias de fadas, que eu acho ótimo, mas dependendo da fase que você esteja...então agora eles estão mudando os livros, estão comprando livros novos... porque eles acham que vão para a $5^{a}$ série, no ano que vem ... quer dizer, eles estão a mil, se eles pudessem, eles faziam um resumo todos os dias... resumo e redação...(Lelis, 1996, p.162-163) '
\end{abstract}

Em comum nas duas práticas a questão da funcionalidade como condição para a produção da leitura. Já não se encontra no relato o menino Graciliano perguntando "para que?", nem tampouco a professora solitária e inadequada tal qual presente na figura de D. Margarida. Ao contrário, constata-se a presença de alunos que se sentem desafiados e de professores que conseguem perceber o por que dos alunos quererem se manter lendo contos de fadas ao invés de avançarem em busca de textos de aventuras e, mais que conseguem levá-los a aceitar o desafio de se reconstruir, de rever seus valores e seus juízos prévios. Mas muitas das vezes, neste contexto, a busca por um material didático-paradidático que dialogue com as intenções do professor se torna exaustiva e infrutífera. Reproduções de preconceitos sociais, coleções pasteurizadas, desconhecimentos básicos quanto ao que venha ser uma foto ou uma ilustração requerem um grande trabalho de garimpagem.

É para este cenário que os editores apresentam seus livros. É para professores como Margarida e Luiza e para alunos como o menino Graciliano e os da 4a. Série do ensino fundamental que os designers preparam o projeto gráfico dos livros, que eles sugerem formatos, se dedicam ao estudo de tipologias e ilustram páginas e mais páginas.Em outras palavras, é com esses agentes que o material didático-paradidático proposto terá de dialogar/informar/formar.

\title{
2. Os limites do designer
}

Ao universo diversificado da sala-de-aula agregam-se então os conceitos provenientes de editores, autores, ilustradores e revisores entre outros que, na seleção e elaboração de materiais didáticos, contribuem para o desenvolvimento de práticas de ensino calcadas ora no modelo comunicacional de Jakobson ora mais próximas de um entendimento da comunicação enquanto processo dialógico.

Concentrando a atenção na atuação do designer, é possível observar que, embora o material didático em construção vá ser utilizado por professores e alunos, a sua ligação com o contexto da futura publicação restringe-se, na grande maioria das vezes, ao encontro com o escritor e com o editor. Por este viés, seu campo de atuação concentra-se no entendimento das necessidades do escritor que serão corroboradas pelo editor.

Assim, o designer concentra-se na elaboração de um "Design para a leitura" (Farbiarz, 2004) de um suporte específico, na maioria esmagadora das vezes, de um livro impresso. Questões de legibilidade, como tipografia, cor, contraste, em prol de uma ilustração que traduza a intenção do escritor dão conta dos limites de sua atuação.

Ora sem entender ora sem ter possibilidade de intervir de forma diferenciada, o designer reforça estereótipos, reproduz ilustrações em que o magro, o branco, o rico são conceitos defendidos, mesmo quando o material didático irá fazer parte de salas-de-aula em que a miscigenação racial seja predominante, por exemplo. Sem se reconhecer, o aluno aumenta o seu grau de insatisfação, e o material didático reproduz os espaços estanques, de não interação, ocupados pela D. Margarida e pelo menino Graciliano que a professora Luiza e os alunos de 4a. Série têm tanto trabalho para desconstruir.

Design pasteurizado, Design de legibilidade, Design estético... (Farbiarz, 2004) Apenas algumas modalidades do material didático que encontramos em livrarias, bibliotecas e salas-deaula. No primeiro caso, cabe ao designer a tarefa de organizar todo e qualquer título dentro de uma mesmo coleção. Do clássico ao pós-moderno, capas semelhantes, padronizadas, tipos idênticos, espaços para ilustração (quando existentes) pré-definidos. No segundo caso, fica o designer responsável pela tradução das intenções da dupla editor-autor, sua contribuição se 


\section{Infodesıgn}

amplia na mesma proporção em que ele intervém na elaboração do projeto gráfico, mas se mantém limitada pela manutenção do conceito de tradução das intenções da dupla editor-escritor. No terceiro caso, a liberdade do designer finalmente entra em cena, mas, infelizmente, o que o cenário tem demonstrado é a valorização de uma "arte pela arte", de um discurso visual destituído de seu contexto.

Quando chegamos as Margaridas e aos Gracilianos do ensino médio, muitas das vezes a situação fica a beira do insustentável. Com um arsenal tecnológico a disposição, o adolescente tende a reproduzir um discurso oficial de valorização da leitura como fonte de cultura, mas, simultaneamente, tende a queixar-se das restrições impostas pelo ato de leitura e pelo suporte livro. Os seguintes trechos, extraídos de redações de estudantes de ensino médio, de uma escola particular da zona sul da cidade do Rio de Janeiro, no ano de 1997, ajudam a esclarecer a questão:

Para que um livro seja tão interessante quanto seu competidor (diferentes mídias) seria essencial uma maior divulgação e incentivo, assim como uma melhoria na apresentação e adequação vocabular ao público direcionado, pois o tamanho das letras e o rebuscamento das palavras afastam o leitor de um possível contato com o livro bem como o custo elevado.

Primeiro passo para solucionar a falta de leitura é se conscientizar dessa problemática. Isto pode ser feito através de debates em escolas, universidades, tentando entender o porquê da não-leitura e levando sempre os pontos positivos que a leitura pode trazer. A família e os professores têm papel fundamental neste processo e podem mostrar que o livro não deve ser visto como obrigação, mas sim como uma diversão.

De repente abaixar o custo dos livros apenas, não seria suficiente para influenciar a leitura nesse meio. A questão é muito mais abrangente porque discute valores e uma educação que vem sendo transmitida ao longo dos tempos e não é quase nunca questionada, devido à acomodação.

Os adolescentes trocam os livros por outros meios de comunicação porque estes oferecem mais dinamismo, rapidez, ou seja, atrativos que prendem a atenção do jovem. Para melhorar essa situação, os jovens deveriam se conscientizar da importância da leitura de livros e os próprios editores poderiam se preocupar em escrever livros que atraiam mais o leitor.

E mais uma vez D. Margarida e o menino Graciliano se sentem abandonados.

\section{A aposta no Design da leitura}

Não seria a hora, enquanto designers, de nos dedicarmos ao desenvolvimento de materiais didáticos em que o projeto gráfico procurasse ser o resultado do entendimento da polifonia de vozes que se fazem presentes no universo educacional? Não seria a hora de escritores e designers atuarem enquanto co-autores em busca do diálogo texto-imagem, ou melhor em busca de um discurso textual que participasse do contexto da sala-de-aula, enriquecendo seus sujeitos, questionando-os? Não seria a hora do designer buscar projetoscondizentes com as possibilidades tecnológicas que se encontram a nossa disposição? Não seria a hora de somarmos ao livro impresso a potencialidade do livro eletrônico e/ou de nos dedicarmos aos jogos eletrônicos já presentes no cotidiano dos adolescentes? Enfim, não seria a hora de somarmos esforços em detrimento de nos restringirmos a manutenção de um status quo determinado pelo mercado?

Pesquisas realizadas por Alexandre Farbiarz, no último PUC por um dia ${ }^{4}, 2005$, para a sua tese de doutorado, dão conta, por exemplo, do interesse do adolescente em ler um livro de aventuras ou um romance no suporte e-book, inacessível a ele atualmente. Não seria a hora do designer buscar alargar as fronteiras do livro? Não teria o designer que buscar materiais didáticos que dialogassem com as múltiplas referências tecnológicas que se encontram disponíveis para o adolescente em nossa sociedade?

Será que de fato não podemos mais? E quando podemos, será que sabemos aproveitar o espaço, ou ficamos presos por desconhecimento?

Será que a observação de Diane Gromala ${ }^{5}$, diretora do New Media Research Lab da University of Washington não deveria ser considerada na formação dos designers voltados para trabalhos no campo da Educação? Em suas palavras:

\footnotetext{
${ }^{4}$ Evento semestral , realizado na Puc-Rio em que os alunos do ensino médio passam um dia nas instalações da Universidade, participando de palestrs, mesas-redondas e oficinas.

${ }^{5}$ Apud Pires (1999).
} 


\begin{abstract}
' Alega-se que estudantes universitários, geralmente denominados como Geração X, estão menos capacitados a ler, não lêem tão bem como antes, e são dispersos. Eu gostaria de concordar, mas ultimamente não posso. Meus próprios estudantes,é verdade, freqüentemente irritam-se ou parecem sentir uma dificuldade real quando são obrigados a ler literatura séria. Eles se contorcem freqüentemente aos 20 minutos de aula. (...) Em contrapartida, eles se sentam em frente à luz oscilante das telas de

computador até alta noite, mantendo arrebatada atenção. Os estudantes de design mais envolvidos com multimídia, invariavelmente, tornam-se aqueles mais obsessivos com a profissão, com os detalhes, encadernação e bibliofilia. Como nossa cultura se reconfigura em resposta à tecnologia eletrônica e o que ela trouxe, eu luto contra a noção de que estes estudantes são menos 'alfabetizados'. Será que isto depende da primazia de literatura séria? Ou nós estamos testemunhando uma troca para uma alfabetização de um tipo diferente, que inclui outras mídias e satisfaz outras necessidades culturais?(Gromala, 1996, p.12) '
\end{abstract}

Kenski (1996) aponta a escola como o único espaço remanescente disponível para a troca. Nas suas palavras já perdemos a transmissão oral do conhecimento que se dava pelo chefe da tribo em torno da fogueira, assim como as praças... Neste sentido privilegiar o modelo comunicacional de Jackobson (1969) seria o mesmo que fechar os olhos para um mundo pósmoderno ou uma sociedade na qual já não se lê Ou isto ou aquilo, de Cecília Meirelles, mas se procura o isto e aquilo ${ }^{6}$ necessário para a prática do diálogo e da interação. Enfim, seria o mesmo que manter a D. Margarida solitária e o menino Graciliano frustrado.

Considero que o Design vive a inovação, se antecipa a ela e a sustenta. Logo se alguma área deve congregar esforços em busca deste projeto, por que não a nossa.

Design pasteurizado, Design de legibilidade, Design estético não estariam indo pelo caminho inverso quando o assunto é material didático/paradidático? À pressão do mercado e a dificuldade em assumir a responsabilidade oriunda de uma proposta interdisciplinar não se integraria a uma falta de dimensão das especificidades de cada realidade?

Pensar em "Design da Leitura" (Farbiarz, 2004) no universo cultural brasileiro é ir além da arte do livro, de um design para a leitura, é uma questão de conduta. Enfim, pensar em "Design da Leitura" é visualizar uma sociedade cujos agentes - editores, escritores, designers, professores, etc... - assumam-se enquanto formadores de opinião. Neste sentido, pensar em Design da leitura é pensar o Design na complexidade da palavra, "não apenas como uma atividade de dar forma a objetos, mas como um tecido que enreda o design, o usuário, o desejo, a forma, o modo de ser e estar no mundo de cada um de nós". (Couto e Oliveira, 1999).

Uma Fabiola moradora de um morro que ri, ilustração de Marcelo Lins ${ }^{7}$, um príncipe mais feio que o sapo, de A Bela e a Fera, Ruy de Oliveira ${ }^{8}$; as dissertações de mestrado de Renata Villanova (2005), Julie Pires (2005) e Ana Paula Zarur Silva (1997) parecem trazer alento para um quadro em que muitas das vezes o Design da informação-formação se transforma em Design da não informação - do preconceito - da repetição quando o assunto é o material didático/paradidático.

Enfim, se o Design, enquanto campo de atuação, se propõe a interdisciplinaridade, ao participar do campo da Educação, ele precisa reconhecer, entender, integrar, expor, e, a medida do possível, ousar, se impor em um meio cuja solidão muitas vezes é a palavra de ordem.

\title{
Agradecimento
}

Agradeço aos membros do Núcleo de Estudos do Design do Livro da PUC-Rio a oportunidade de desenvolvermos juntos o conceito "Design da leitura". Sem dúvida meu olhar interdisciplinar, fruto de um mestrado em Letras e de um Doutorado em Educação, só encontrou o seu espaço junto a um grupo que entende, de fato, o Design como um campo de vocação interdisciplinar.

\section{Referências}

Bakhtin, Mikhail (1981). Marxismo e filosofia da linguagem. São Paulo: Hucitech.

Chartier, Roger (org.). (1996). Práticas de leitura. São Paulo: Estação Liberdade.

Couto, Rita M. e Oliveira Alfredo J. (org) (1999). Formas do design. Rio de Janeiro: PUCRio/2AB.

Dietzsch, Mary Julia M. e Silva, Maria Alice S. S. (1994). Itinerantes e itinerários na busca da palavra. Cadernos de Pesquisa 88. 


\section{Infodesıgn}

Dietzsch, Mary Julia M. (1996). Além das Páginas do Livro Didático. Em Aberto 16, 69.

6 Concepção exposta por Mignot, apud Lelis (1996)

7 Benevides, Ricardo (2000). Fabíola foi ao vento. Rio de Janeiro: Revan.

8 Oliveira, Ruy (1994). A Bela e a Fera. São Paulo: FTD. Livro cuja narrativa é contada unicamente pela ilustração, recebeu o prêmio Jabuti de 1995 e o prêmio melhor livro de imagem FNLIJ,1994.

Farbiarz, Jackeline (2001). Utopia e realidade na atuação do professor de língua e literatura. Tese de Doutorado não publicada. Faculdade de Educação. Universidade de São Paulo, BR.

Farbiarz, Jackeline e Farbiarz, Alexandre (2004). O designer como mediador entre o livro e o leitor. Anais do P\& D Design 2004, São Paulo, FAAP.

Iser, Wolfgang (1978). The act of reading, I-2. Baltimore: The Johns Hopkins University Press.

Jackobson, Roman (1969). Linguística e comunicação. São Paulo: Cultrix.

Kenski, Vani Moreira (1996). Memória e conhecimento na era tecnológica. Manuscrito não publicado.

Konder, Leandro (1996). O outro esse alienígena. Jornal O Globo, 25 de agosto de 1996.

Lelis, Isabel Alice (1996). A polissemia do magistério entre mitos e histórias. Tese de Doutorado não publicada. Pontifícia Universidade Católica do Rio de Janeiro, BR.

Lima, Emilia Freitas de (1996). Começando a ensinar: começando a aprender?. Tese de Doutorado não publicada. Universidade de São Carlos, BR.

Lima, Renata Vilanova (2005). Vi Lobato, através de Emília: Emílias ilustradas para três fases de Lobato. Dissertação de Mestrado não publicada. Departamento de Artes \& Design. Pontifícia Universidade Católica do Rio de Janeiro, BR.

Pires, Julie de Araújo (1999). A reconstrução do livro: um estudo em design acerca das possibilidades do livro a partir da hipertextualidade eletrônica. Dissertação de Mestrado não publicada. Departamento de Artes \& Design. Pontifícia Universidade Católica do Rio de Janeiro, $B R$.

Silva, Ana Paula Zarur de Andrade. (1997). Por um estudo do significado da ilustração no livro infantil brasileiro. Dissertação de Mestrado não publicada. Departamento de Artes \& Design. Pontifícia Universidade Católica do Rio de Janeiro, BR.

\section{Sobre os autores}

Jackeline Lima Farbiarz é doutora em Educação e Linguagem pela USP, Mestre em Letras pela PUC-Rio. Professora do Departamento de Letras da PUC-Rio. Supervisora de Pesquisa do Núcleo de Estudos do Design do Livro, vinculado ao Laboratório de Comunicação do Programa de Pósgraduação do Departamento de Artes \& Design da PUC-Rio.

alexfarbiarz@aol.com

Alexandre Farbiarz é doutorando em Design pela PUC-Rio; Mestre em Educação e Linguagem pela USP e em Design pela PUC-Rio; Professor do curso de Comunicação Social da UFF, Supervisor Administrativo do Núcleo de Estudos do Design do Livro, vinculado ao Programa de Pós-graduação do Departamento de Artes \& Design PUC-Rio.

alexfarbiarz@aol.com 